\title{
PENGEMBANGAN DSS \\ UNTUK MENENTUKAN METODE PELATIHAN E-LEARNING BERBASIS MOODLE BAGI GURU SMK
}

\author{
Muslikhin \\ Program Studi Pendidikan Teknologi dan Kejuruan PPs UNY \\ forward2701@yahoo.co.id \\ Eko Marpanaji \\ Fakultas Teknik Universitas Negeri Yogyakarta \\ eko@uny.ac.id \\ Abstrak
}

\begin{abstract}
Penelitian ini bertujuan menghasilkan desain DSS dan mengetahui kualitas DSS yang dipakai instruktur dalam menentukan metode pelatihan e-learning berbasis Moodle bagi guru SMK.Penelitian dan pengembangan ini melalui lima fase yaitu: asesmen/analisis, desain, pengembangan, implementasi dan evaluasi. Subyek penelitian adalah guru SMK di Kota Yogyakarta, Sleman dan Magelang 75 responden need assessment and analysis, 15 guru uji beta, 24 guru untuk evaluasi. Instrumen pengumpulan data berupa lembar kuesioner need assessment and analysis, lembar validasi ahli pelatihan, lembar uji alfa, lembar uji beta dan lembar evaluasi pelatihan.HasilpenelitianmenunjukkanDSS memberikan alternatif keputusan secara cepat melalui empat pertimbangan berdasarkan peserta, tujuan, keuntungan, dan level. Hasil uji alfa dan beta DSS menunjukkanskor 4,14dan 4,02 atau kategori "baik". SedangkanakurasiDSS melalui evaluasi terhadap 24 pesertapelatihane-learningmenunjukkan 88,14\%akurat.
\end{abstract}

Kata kunci: DSS, pengambilan keputusan, menentukan metode,pelatihan e-learning.

\section{DEVELOPING A DSSFOR DETERMINING THE METHOD OF MOODLE-BASEDE-LEARNINGTRAINING FOR VOCATIONAL HIGH SCHOOL TEACHERS}

\begin{abstract}
This study aims to produce the DSS design and knowing the quality of the DSS is used in determining instructor training method based on Moodle e-learning for Vocational High School teachers. This study was a research and development conducted in five steps, i.e. need assessment/analysis, design, development, implementation and evaluation. The subject was teachers of SMK at Yogyakarta City, Sleman and Magelang, there were 75 respondents for needs assessment and analysis 15 teachers for beta testing, 24 teachers for evaluation. The instruments of the data collection were validation sheets for the needs assessment and analysis, alpha test sheets, beta test sheets and training evaluation sheets. The result of the study shows the following: the DSSprovides an alternativerapiddecisionsthroughfourconsiderationsbased on: participants, objectives, benefits, andlevel.The Alpha test and Beta test results show a mean score of 3.92 and 4.02 or the DSS is in the "good" category. While, the accuracy of the DSS through an evaluation of 24 participants of the e-learning training shows $88,14 \%$ accuracy.
\end{abstract}

Keywords: DSS, decision making, determine methods, e-learning training 


\section{PENDAHULUAN}

Teknologi informasi dan komputer (TIK) merupakan keniscayaan dalam dunia pendidikan masa kini dan masa depan. TIK yang berkembang sangat pesat saat ini, mendapat sambutan positif oleh masyarakat. Terbukti berbagai layanan masyarakat telah menerapkan TIK, sehingga tidak asing bagi kita dengan istilah $e$-business, e-commerce, $e$ banking, e-government, e-mail, hingga $e$ learning. Istilah terakhir sering dikaitkan dengan implementasi pembelajaran berbasis TIK, terutama e-learning dimanfaatkan sebagai alat bantu pembelajaran, sehingga sekolah perlu melakukan analisis kebutuhan, penyiapan kebutuhan yang diperlukan, perancangan model pembelajaran serta pengembangannya.

Secara implisit, e-learning masuk ke dalam kurikulum melalui mata pelajaran Keterampilan Komputer dan Pengelolaan Informasi (KKPI) di jenjang pendidikan menengah. Selain itu respon baik dari Kementerian Pendidikan dan Kebudayaan terhadap perkembangan dunia TIK diwujudkan dengan dibentuknya Jaringan Pendidikan Nasional (Jardiknas). Kebijakan ini bertujuan agar peserta didik memiliki bekal kemampuan untuk mengenal, memahami, dan berinteraksi dengan dunia TIK.

Sejak dibentuk tahun 2007 hingga 2011, Jardiknas mempunyai fungsi melakukan integrasi TIK dalam pembelajaran, memanfaatkan TIK dalam pengelolaan manajemen pendidikan serta berbagai kegiatan pendidikan dan pelatihan terkait pemanfaatan TIK. Selain itu, implementasi TIK secara nasional dalam pendidikan mempunyai manfaat antara lain: (1) meningkatkan kecepatan layanan informasi yang integral, interaktif, lengkap, akurat dan mudah didapat; (2) memberikan pelayanan data dan informasi pendidikan secara terpadu; (3) menciptakan budaya transparan dan akuntabel; (4) merupakan media promosi pendidikan yang handal; (5) meningkatkan komunikasi dan interaksi baik secara lokal maupun internasional; (6) mengakses berbagai bahan ajar dari seluruh dunia; dan (7). Meningkatkan efisiensi dari berbagai kegiatan pendidikan (diakses tanggal 10 Agustus 2012 dari http:// jardiknas.kemdiknas.go.id/).

Hal senada juga digagas dalam Roadmap ASEAN Community 2009-20015 yang memiliki tujuan strategis, salah satu pionnya melaksanakan program pengembangan sumber daya manusia yang akan memfasilitasi pelaksanaan TIK di daerah. Untuk itu dalam roadmap tersebut menekankan pada tindakan: (1) melaksanakan program peningkatan kapasitas TIK di ASEAN, termasuk bagi perempuan, anak, orang tua dan orang cacat; (2) mempromosikan penggunaan positif dari TIK di khususnya internet; (3) mendorong pengenalan TIK di semua tingkat pendidikan; (4) memulai penggunaan awal TIK di sekolah dasar; (5) meningkatkan penggunaan TIK untuk mempromosikan e-learning, dan (6) mengembangkan tenaga kerja dan dengan tingkat keahlian TIK tinggi (Roadmap ASEAN Community, 2009, p.70).

Berdasarkan pra-survei yang dilakukan antara 6 September s/d 4 Oktober 2012 di beberapa SMK di Kota Yogyakarta dan Kabupaten Bantul, terungkap bahwa relatif belum banyak sekolah yang menggunakan $e$ learning sebagai alat bantu dalam proses pembelajaran. Hasil temuan sementara, SMK yang memiliki portal e-learning sebagian besar merupakan eks SMK RSBI/SBI. Kondisi ini tidak jauh berbeda dengan hasil studi Jardiknas Jawa Tengah, yang menyebutkan bahwa masih sangat rendah usaha dan kegiatan yang mengarah pada penguatan implementasi e-learning optimal pada proses belajar mengajar di SMK.

Rendahnya implementasi $e$-learning selain karena minat guru terhadap e-learning kurang, juga karena belum mampu mempelajari dan memahami materi e-learning secara mandiri akibat keterbatasan waktu, tenaga, serta pikiran. Kondisi inilah yang membuat sebagian besar guru SMK belum terbiasa dan cenderung enggan menggunakan e-learning dalam proses pembelajaran. Juga belum banyak SMK berstatus negeri di Jawa Tengah yang telah mengimplementasikan e-learning secara penuh untuk semua mata pelajaran yang ada. Implementasi $e$ learning yang ada secara umum sebatas pada mata pelajaran yang terkait langsung dengan komputer (misalnya KKPI) atau mata pelajaran yang diampu oleh guru dengan latar belakang TIK.

Pada tahun 2010 di Jawa Tengah diketahui hanya ada $5,7 \%$ SMK berstatus negeri yang telah mengimplementasikan e-learning, yaitu di SMK Negeri 1 Purwodadi dapat diakses di http://smkn1-purwodadi.net/ dan 
SMK Negeri 2 Pekalongan dapat diakses di http://smk2pekalongan.sch.id/. Model implementasi yang dilakukan di dua sekolah SMK tersebut berbeda secara implementasi teknologi, meskipun sama dalam tujuan yang ingin, yaitu mengimplementasikan model pembelajaran berbasis e-learning. Dari kedua contoh impelementasi tersebut, di SMK Negeri 1 Purwodadi dapat dikatakan hampir secara penuh semua mata pelajaran telah memiliki course di e-learning (LMS Moodle), sedangkan yang telah dilakukan oleh SMK Negeri 2 Pekalongan masih bertumpu pada ketersediaan basis data modul, e-book dan ketersediaan soal-soal yang belum interaktif.

Jika dicermati dari hasil studi Jardiknas sejak 2007 hingga hasil prasurvei 2012, perkembangan e-learning belum sebagai pioneer project untuk SMK lain di luar eks RSBI/SBI. Setidaknya hal itu terindikasi dari relatif belum ada SMK berstatus negeri maupun swasta di luar eks RSBI/SBI yang memiliki $e$ learning dan berjalan optimal. Implementasi e-learning ke SMK sendiri merupakan tantangan tersendiri untuk saat ini. Sebelum keputusan Mahkamah Konstitusi yang menyatakan pelaksanaan RSBI/SBI melanggar kontitusi, e-learning merupakan bagian kewajiban bagi SMK RSBI/SBI, seperti yang diamanatkan melalui Permendiknas No. 78 tahun 2009. Dalam Permendiknas dikatakan salah satu poin berisi penerapan proses belajar yang dinamis dan berbasis TIK. Saat ini dengan diberhentikannya RSBI/SBI maka penetrasi e-learning di SMK menjadi semakin berat.

Jardiknas sendiri dalam hal ini berperan sebagai lembaga pelatihan dan pendidik implemantasi e-learning. Pelatihan yang dilakukan Jardiknas tertuang dalam dua bentuk, pertama Jardiknas mengambil perwakilan guru TIK/KKPI dari SMK RSBI/SBI untuk mengikuti pelatihan e-learning, kedua Jardiknas terjun langsung ke SMK di daerahdaerah untuk mengadakan pelatihan e-learning di SMK tersebut. Materi yang dilatihkan mulai dari instalasi LMS Moodle hingga penggunaannya baik sebagai administrator, manager, course creator maupun teacher.

Adapun hasil dari pelatihan e-learning oleh Jardiknas diharapkan para guru dari beberapa SMK dapat mengimplementasikan e-learning setelah kembali ke masing-masing sekolah. Jardiknas memilih LMS Moodle ka- rena pertimbangan open source, aspek kemudahan dan memiliki fitur yang lengkap dibanding LMS lainnya seperti Lectora, Dokeos, Doceboo atau BlackBoard. Manfaat lain dari e-learning adalahberbagai peluang untuk menangkap, menyimpan dan mendistribusikan informasi dan sumber daya dari semua jenis dan format. Baik dalam format teks, gambar dan ilustrasi, multimedia, simulasi tetapi murah dan diakses secara real time untuk menunjang pembelajaran (Naidu, 2006, p.7).

E-learning yang diterapkan secara premature menyebabkan e-learning tersebut tidak berjalan sebagaimana rancangan awal, atau setidaknya akan melenceng dari harapan dan akhirnya terbengkalai. Di lapangan konsekuensi tersebut merupakan permasalahan yang sering timbul setelah dibangun $e$ learning. Untuk mengatasi hal tersebut, pihak sekolah melakukan pelatihan bagi para guru. Umumnya instruktur mengulang metode dan materi seperti apa yang diterima instruktur saat dilatih oleh Jardiknas atau oleh institusi lain (perguruan tinggi), tanpa melihat variabel-variabel penentu keberhasilan pelatihan. Padahal jika dilihat secara mendalam relatif tidak sama dalam setiap unsur pelatihan. Misalnya latar belakang pendidikan yang berbeda, pangkat dan golongan, usia, beban mengajar, gender, motivasi, gaya belajar dan unsur lainnya (Kubr \& Prokopenko, 1989, p.237).

Pelatihan yang tidak metodis atau dengan mengabaikan unsur-unsur penentu keberhasilan pelatihan, hanya akan membawa dampak "doroty sayer". Istilah tersebut merupakan julukan bagi sebuah program yang dilakukan dengan menghabiskan SDM, waktu, biaya, dan tenaga akan tetapi tidak memberi dampak apa-apa setelah program itu terlaksana. Lebih khusus pada biaya umumnya untuk penyelenggaraan OJT (on job training) setidaknya ada beberapa yang dibutuhkan bagi peserta (materi ajar, akomodasi dan transportasi), instruktur (honorarium, transportasi, dan akomodasi) dan prasarana pelatihan (modul, ATK, materi ajar, dll.). Perlu diketahui bahwa anggaran untuk penyelenggaraan sebuah pelatihan membutuhkan biaya cukup besar, sehingga sedapat mungkin "doroty sayer" dapat diminimalisir. Dengan demikian diupayakan sebuah metode, strategi atau teknik yang sesuai dengan pendekatan 
pelatihan terhadap perilaku calon peserta yang akan dilatih.

Menghindari efek "doroty sayer" tentu merupakan suatu hal penting. Mengingat begitu urgent pelatihan demi berjalannya $e$ learning di SMK, maka perlu ada berbagai upaya pelatihan yang efektif. Sebenarnya tugas guru yang telah mendapat pelatihan $e$ learning bukan sebatas membuat (instalasi) $e$ learning tetapi harus dibarengi dengan upaya tim/institusi agar sistem yang telah dibuat dapat mendukung Proses Belajar Mengajar (PBM). Upaya yang dimaksud setidaknya merujuk ke sosialisasi melalui pelatihan e-learning bagi para guru. Sangat ironis, manakala $e$ learning mulai dipakai di SMK eks RSBI/SBI (meskipun belum optimal), justru keberadaan program e-learning oleh Jardiknas per 1 Januari 2012 melalui Surat Kapustekkom No. 3266/P1.4/TP/2011 tanggal 28 Desember 2011 perihal Penghentian Layanan Jardiknas, Zona Sekolah (SchoolNet) tahun 2011 maka secara resmi program internalisasi e-learning di SMK.

Analisis Goldstein \& Ford (2003:220) mengutarakan secara umum dilema yang dihadapi dalam pemilihan metode dan teknik pelatihan secara terorganisir berdasarkan pada variabel-variabel penentu keberhasilan pelatihan. Pelatihan menjadi kunci skill guru terhadap e-learning, karena melalui guru transfer skill kepada peserta didik akan dilakukan dan pada akhirnya akan menjadi terbiasa (del Mar, 2006, p. 158). Penelitian Rosen (1993) menunjukkan bahwa guru tidak mau menggunakan CBT (Computer Based Teaching) karena kurangnya pengalaman mengajar dengan TIK dan kurangnya dukungan teknis bagi para guru. Permasalahan dalam CBT tidak jauh berbeda dengan pelaksanaan e-learning di SMK. Itu artinya habit guru dalam mengoperasikan dan mengelola e-learning perlu dibiasakan melalui pelatihan, selain itu kultur juga berpengaruh pada implementasi e-learning (Adwan, 2012, p .123).

Temuan sementara, e-learning di SMK dari hasil prasurvei pada 1 Sepetember - 4 Oktober 2012 di SMK Muhammadiyah 3 Yogyakarta, SMK Negeri 2 Depok, dan SMK Negeri 1 Sedayu menunjukkan bahwa ada beberapa masalah mendasar, bahwa keberhasilan e-learning ditentukan oleh kualitas pelatihan e-learning terhadap guru. Akan tetapi pelatihan yang ada umumnya kurang berdampak optimal terhadap kemampuan skill guru, penyebabnya antara lain: (1) materi yang tidak tepat, (2) tujuan atau hasil pembelajaran tidak disebutkan dalam pelatihan, (3) metode yang tidak tepat, (4) apatisme guru terhadap e-learning, (5) usia peserta, (6) latar belakang pendidikan, (7) instruktur memandang semua peserta sama, (8) keterbatasan anggaran hingga, (9) keluhan pada jaringan. Sesungguhnya masalah-masalah tersebut dapat diselesaikan melalui perencanaan pelatihan, akan tetapi pelatihan yang tidak metodis hanya akan menimbulkan masalah baru, dan ini disadari betul bahwa memilih metode pelatihan yang tepat akan berdampak pada keberhasilan pelatihan.

Lebih jauh mengenai pemilihan metode apa yang akan digunakan dalam pelatihan $e$ learning maka perlu adanya studi analisis kebutuhan. Oleh sebab itu dibutuhkan instrumen untuk mengukur dan mendiagnosa permasalahan penyelenggaraan pelatihan e-learning yang cukup kompleks. Keputusan menentukan metode pelatihan yang tepat sesungguhnya dapat dilakukan oleh ahli atau pakar pelatihan e-learning. Lalu siapa yang kita anggap sebagai ahli pelatihan e-learning? Saat ini untuk memilih metode apa yang digunakan, umumnya saat ini melalui diskusi dengan ahli. Akan tetapi "ahli" dalam hal ini relatif pada penilaian individu dan cenderung subjektif, sehinggga butuh instrumen yang mampu membantu mengarahkan pada penentuan keputusan metode yang tepat untuk dipakai.

Secara teori, menurut Lynton \& Pareek (1992, p. 160) ada tujuh metode pelatihan yang dikenal: lapangan, simulasi, laboratorium, kasus, individual, seminar, serta ceramah. Masing-masing metode tersebut memiliki kelemahan dan keunggulan tersendiri. Percaya pada tradisi/kebiasaan menyebabkan para manajer pelatihan mengambil keputusan yang sama dengan keputusan terdahulu untuk masalah atau kesempatan yang berbeda. Langkah meminta saran kepada yang berwenang atau mengambil keputusan berdasarkan saran seorang ahli atau tingkat manajer yang lebih tinggi lebih baik dibanding memilih metode pelatihan berdasar tradisi/kebiasaan. Manajer pelatihan yang memakai pendekatan rasional, cerdik dan sistematis akan mencapai solusi lebih baik.

Dalam teori pengambilan keputusan, untuk menentukan atau memilih metode pe- 
latihan yang tepat tidaklah mudah. Karena pengambilan keputusan ini terkait dengan kemampuan manajerial dipadu dengan kemampuan instruksional. Artinya bukan sembarang orang kompoten untuk menentukan metode apa yang tepat tanpa sebuah analisis kebutuhan. Menurut buku "Assessing Training Needs" karya Brown \& Wedel $(1974$, p. 81) untuk memilih metode pelatihan dapat dilakukan dengan cara membuat formulasi dari assesmen pelatihan ke dalam metode pelatihan. Selain itu pengambilan keputusan untuk menentukan metode pelatihan e-learning merupakan permasalahan yang semi atau bahkan tidak terstruktur, tentu kondisi ini perlu "jalan tengah" yang cermat.

Pendekatan solusi untuk pengambilan keputusan dalam menentukan metode pelatihan dapat dilakukan salah satunya dengan software. Hal ini dikarenakan kemungkinan permasalahan dapat diformulasikan atau dibuat ke dalam bentuk matematika pemrograman linier atau alasan semi/tidak terstruktur (Naser, et.al, 2011, p.4). Hasil penelitian disertasi Ardian (2012) menunjukkan kecenderungan pengambilan keputusan dapat dibantu dengan Decision Support System (DSS). Dalam studi tersebut, DSS dapat digunakan untuk mendukung pengambilan keputusan membuka program studi baru di sebuah perguruan tinggi dan jika dibandingkan dengan analisis manual didapati $95 \%$ hasil putusan sama.

Turban (2005) mendefinisikan DSS sebagai sistem berbasis komputer, yang membantu para pengambil keputusan untuk menggunakan data dan berbagai model dalam memecahkan masalah-masalah tidak terstuktur atau semi terstruktur. Sistem yang dimaksud adalah pengembangan konsep DSS yang dapat dibangun menggunakan bermacam program aplikasi. DSS sendiri dapat juga dikatakan sebagai sistem komputer yang mengolah data menjadi informasi untuk mengambil keputusan dari masalah semi-terstruktur yang spesifik. DSS dapat digambarkan sebagai sistem yang berkemampuan mendukung analisis ad hoc data, dan pemodelan keputusan, berorientasi keputusan, orientasi perencanaan masa depan dan digunakan pada saat-saat yang tidak biasa. Secara umum tujuan dari DSS adalah (1) membantu menyelesaikan masalah semi terstruktur, (2) mendukung manajer dalam mengambil keputusan dan (3) me- ningkatkan efektifitas bukan efisiensi pengambilan keputusan (Kusrini, 2007 p. 25).

Permasalahan di atas menjadi menarik untuk diteliti lebih lanjut secara terintegrasi, pokok masalah berupa kebutuhan software yang mampu membantu pengambilan keputusan untuk menetukan model pelatihan $e$ learning, ujicoba hasil dan analisis terkait proses dan hasil produk.

Menurut Frize \& Frasson (2000, p. 268), DSS ke depan menjadi bagian penting dalam pendidikan. Pendapat tersebut meyakinkan asumsi bahwa permasalahan pemilihan metode pelatihan e-learning kontemporer dapat diselesaikan bukan sekadar dari disiplin ilmu pendidikan dan pelatihan, akan tetapi juga erat kaitan dengan bidang ilmu informatika, sehingga dapat memberi manfaat bagi perkembangan e-learning di SMK.

Tujuan dari penilitian ini adalah untuk: (1) menghasilkan desain DSS dalam membantu instruktur menentukan metode pelatihan e-learning berbasis Moodle bagi guru SMK. (2) Mengetahui kualitas DSS yang dipakai instruktur dalam menentukan metode pelatihan e-learning berbasis Moodle bagi guru SMK.

\section{METODE PENELITIAN}

Penelitian ini masuk dalam prosedur R\&D karena hasil penelitian berorientasi pada produk. Apabila produk tersebut telah mendapat validasi serta pengakuan dari ahli melalui uji alfa, baru kemudian uji beta dan dievaluasi pada pelatihan e-learning sesungguhnya. Pengembangan DSS ini merujuk pada model yang ditawarkan oleh Lee \& Owens (2004) yang digabung dengan model Pressman (2010).

\section{Model Pengembangan}

Penelitian ini masuk dalam prosedur R\&D karena hasil penelitian berorientasi pada produk. Apabila produk tersebut telah mendapat validasi serta pengakuan dari ahli melalui uji alfa, baru kemudian uji beta dan dievaluasi pada pelatihan e-learning sesungguhnya. Pengembangan DSS ini merujuk pada model yang ditawarkan oleh Lee \& Owens (2004) digabung model Pressman (2010). Dipilih Pressman, karena model ini cenderung pada pengembangan softwareengineering dibanding multimedia pembelajaran. Model 
Pressman diadopsi untuk memperkuat fase pengembangan model Lee \& Owens dengan memasukkan white box testing, dan black box testing, dimana terletah pada spiral 3 dan 4. Sehingga kombinasi model Lee \& Owens fase pengembangaan, dengan model Pressman (2010) tampak seperti gambar 1.

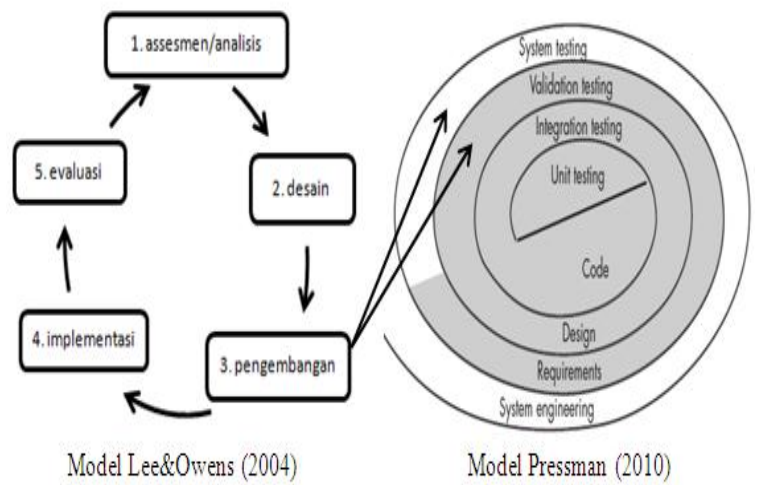

Gambar 1. Alur Pengembangan Model Lee \& Owens dan Pressman

\section{Waktu dan Tempat Penelitian}

Penelitian dan pengembangan ini dilakukan secara bertahap. Untuk fase assessmen/ analisis, fase desain dan fase pengembangan dilakukan Januari s/d April 2013. Sedangkan fase implementasi (uji beta) dilakukan pada 9 April s/d 3 Mei 2013 di SMK Bumantara Magelang, SMK Muhammadiyah 3 Yogyakarta dan SMKN 2 Depok Sleman. Khusus untuk fase evaluasi dilakukan pelatihan $e$ learning di SMKN 1 Kalasan Sleman pada 23 Juni 2013.

\section{Subyek Coba}

Penelitian ini menggunakan dua subyek coba yaitu subyek coba uji beta dan subyek coba fase evaluasi. (a) Subyek Coba Uji Beta terdiri dari tiga kategori kelompok pengguna. Kategori potential user diplih SMK Negeri 2 Depok, kategori average user diplih SMK Muhammadiyah 3 Yogyakarta dan slow learner user dipilih SMK Bumantara Magelang, masing-masing dipilih 5 guru. Alasan pemilihan subyek di sekolah tersebut didasarkan dari data bahwa di SMK Negeri 2 Depok setidaknya telah dilakukan 4 kali pelatihan $e$ learning dalam 2 tahun terakhir, di SMK Muhammadiyah 3 Yogyakarta dilakukan 2 kali pelatihan dalam 2 tahun terakhir, sedangkan di SMK Bumantara Magelang hingga saat ini belum pernah. (b) Subyek Coba Lapangan (Evaluasi) dipilih SMK Negeri 1 Kalasan, dengan jumlah peserta ditargetkan 24 guru.

\section{Prosedur Pengembangan}

Pelaksanaan R\&D terdiri dari dua prosedur yang digunakan yaitu penelitian dan pengembangan. Prosedur penelitihan menggunakan fase asesmen/analisis dan fase evaluasi, sedangkan prosedur pengembangan berisi fase desain, fase pengembangan dan fase implementasi. Prosedur pengembangan DSS dilakukan melalui fase-fase seperti diilustrasikan dalam gambar 2 .

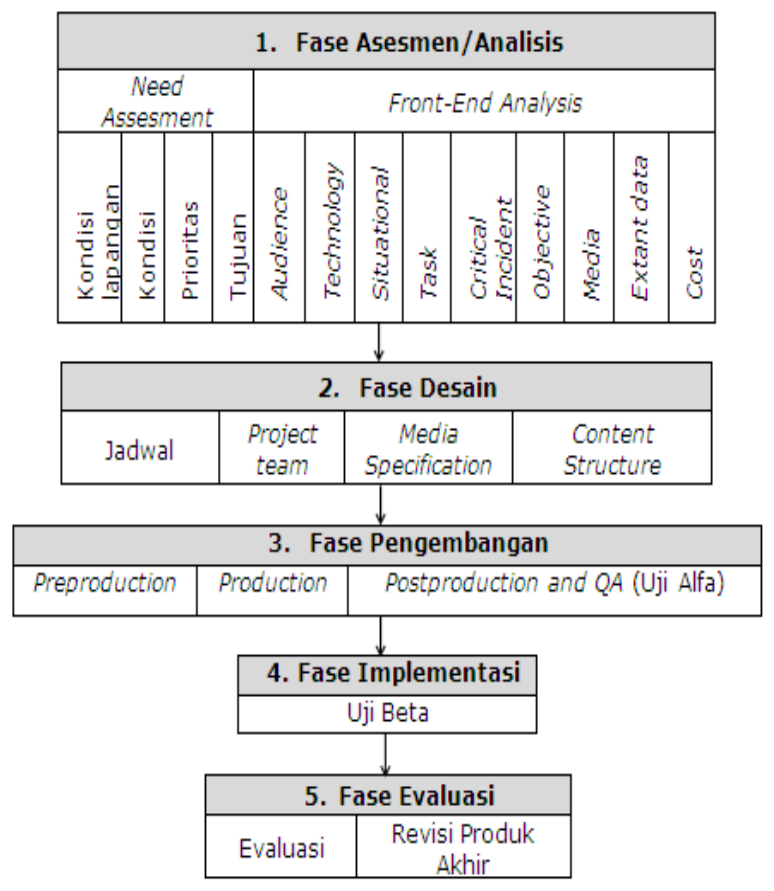

Gambar 2. Fase dalam Prosedur R\&D Model Lee \& Owens (2005)

\section{Jenis Data dan Teknik Pengumpulan Data}

Jenis data yang dihasilkan dalam penelitian ini ada dua jenis. Data kualitatif diperoleh dari hasil need assesmen/analysis DSS, uji alfa, dan uji beta dan, data kuantitatif diperoleh dari hasil evaluasi.Penelitian ini meliputi dua kegiatan, yaitu pengembangan produk DSS dan evaluasi DSS sehingga diperlukan instrumen spesifik. Instrumen pengumpul data untuk pengembangan produk: (a) angket fase need assessment and analysis; (b) angket mengukur hasil uji alfa; (c) dan angket mengukur hasil uji beta. 


\section{Teknik Analisis Data}

Dalam penelitain R\&D tidak melakukan uji hipotesis. Tahap pertama, penelitian menguji kelayakan produk DSS yang digunakan dalam menentukan metode pelatihan $e$ learning. Tahap kedua, fokus penelitian pada evaluasi DSS terhadap pengguna. Teknik yang digunakan untuk menilai akurasi DSS, melalui Likert (skala 5). Skor yang diperoleh kemudian dikonversikan men-jadi nilai, pada skala 5 (Sukardjo,2005, p.55).

Tabel 1. Konversi Data Kualitatif Menjadi Data Kuantitatif (Skala 5)

\begin{tabular}{clr}
\hline Skala & \multicolumn{1}{c}{ Kriteria } & \multicolumn{1}{c}{ Hasil } \\
\hline 5 & Sangat Baik & $\mathrm{X}>4,2$ \\
4 & Baik & $3,4<\mathrm{X} \leq 4,2$ \\
3 & Cukup & $2,6<\mathrm{X} \leq 3,4$ \\
2 & Kurang & $1,8<\mathrm{X} \leq 2,6$ \\
1 & Sangat Kurang & $\mathrm{X} \leq 1,8$ \\
\hline
\end{tabular}

Selanjutnya, pengukuran akurasi dilakukan untuk mengetahui hasil ukur empiris (Xn) sedekat mungkin dengan kondisi ideal (Yn), atau dapat diumuskan seperti berikut (JCGM, 2008:21):

$$
\begin{aligned}
& \% \text { akurasi }=100-\% \text { error } \\
& \% \text { error }=\frac{\mathrm{e}}{\mathrm{Yn}} \times 100 \\
& \mathrm{e}=\mathrm{Yn}-\mathrm{Xn}
\end{aligned}
$$

\section{HASIL PENELITIAN DAN PEMBAHASAN}

\section{Hasil Need Assessment and Analysis (NAA)}

Data yang diperoleh dari NAA, merupakan data untuk mengungkap sekaligus acuan dalam pengembangan produk, meskipun DSS sendiri sebagai jawaban kebutuhan masa depan akan tetapi sesuai prosedur, NAA tetap dilakukan. Analisis berikut berdasar temuan di lapangan. Kondisi lapangan dari 7 SMK yang tersebar di Kota Yogyakarta, Kabupaten Sleman, Kabupaten Bantul dan Kabupaten Magelang menunjukkan hasil yang beragam, hasil disajikan pada Tabel 2 .
Tabel 2. Hasil NAA yang Dilakukan di 7 SMK

\begin{tabular}{lcc}
\hline \multicolumn{1}{c}{ Indikator yang dinilai } & \multicolumn{2}{c}{ Frekuensi } \\
& Ya & Tidak \\
\hline $\begin{array}{l}\text { Pernah mengajar dengan } e \text { - } \\
\text { learning }\end{array}$ & 28 & 47 \\
$\begin{array}{l}\text { Pernah mendapat pelatihan } \\
\text { Instruktur menggunakan metode } \\
\text { tertentu }\end{array}$ & 39 & 36 \\
$\begin{array}{l}\text { Instruktur melakukan analisis } \\
\begin{array}{l}\text { Guru berharap mampu ber } e- \\
\text { learning }\end{array}\end{array}$ & 21 & 54 \\
$\begin{array}{l}\text { Perlu analisis karakteristik } \\
\text { peserta }\end{array}$ & 73 & 2 \\
$\begin{array}{l}\text { Setuju instruktur menggunakan } \\
\text { metode tertentu }\end{array}$ & 71 & 4 \\
Menghendaki DSS online & 60 & 15 \\
\hline
\end{tabular}

Kondisi di lapangan dari 75 responden guru yang diambil menunjukkan hanya 37,3\% para guru pernah mengajar memanfaatkan $e$ learning di SMK. Sedangkan guru yang pernah mendapat pelatihan e-learning sebesar $52,4 \%$. Ini artinya hanya sekitar $15,1 \%$ guru setelah mendapat pelatihan akan menerapkan hasil pelatihan tersebut dalam PBM. Sedangkan jika responden ditanya apakah instruktur menggunakan metode tertentu dalam pelaksanaan pelatihan e-learning sebanyak $37,3 \%$ menjawan "ya" dan $62,7 \%$ menjawab tidak.

Dari total 75 responden guru yang disurvei hanya ada 21 responden $(28 \%)$ yang memberi jawaban ketika ditanya apakah instruktur melakukan analisis kondisi peserta selebihnya $72 \%$ tidak. Saat guru ditanya mengenani kondisi ideal, misalnya responden ditanya harapan guru mampu mengajar menggunakan e-learning dari 75 responden 98,7\% menjawab "ya". Begitu pula saat responden ditanya apakah guru SMK perlu mendapat pelatihan yang metodis, sebanyak 97,3\% menjawab "ya" atau sisanya hanya 2 responden yang menjawab "tidak".

Kondisi ideal dari temuan NAA, para responden berekspektasi perlu analisis karakteristik peserta agar pelatihan e-learning yang dilakukan optimal. Data menunjukkan $97,3 \%$ responden menyatakan perlu, sisanya $2,7 \%$ 
menyatakan tidak perlu. Selanjutnya apabila ditanya mengenai apakah responden setuju bila instruktur menggunakan metode tertentu yang bersal dari analisis karakteristik peserta, $94,7 \%$ menyatakan "ya" dan sisanya 5,3\% atau setara 4 responden menyatakan "tidak". Dalam NAA ini juga mengungkap bentuk aplikasi teknologi yang dikehendaki oleh calon pengguna, mayoritas calon pengguna menghendaki DSS yang dikembangkan dalam bentuk online $80 \%$ dan $20 \%$ menghendaki offline.

Mengenai analisis situasional juga dilakukan dalam NAA ini, responden ditanya mengenai perlukah analisis manual meskipun DSS telah dipakai. Sebanyak $88 \%$ menyatakan masih perlu dan sisanya $12 \%$ menyatakan tidak perlu. Terkait (extant data) pengembangan materi pelatihan, saat ditanya apabila responden memiliki materi pelatihan e-learning boleh diminta untuk bahan pengembangan? Jawaban responden $72 \%$ mempersilahkan sisanya $28 \%$ tidak memperkenankan.

Sedangkan mengenai biaya penggunan software $100 \%$ responden menghendaki DSS tersebut gratis. Dengan alasan itu dua hal yang seharusnya dilakukan pada analisis biaya yaitu; a) melaksanakan cost-benefit analysis, danb) menetapkan return on investment (ROI) tidak dilakukan karena DSS memang digratiskan sesuai hasil NAA.

\section{Hasil Produk DSS}

Hasil produk DSS dapat diakses di www.lumintumedia.com. Untuk melihat hasil, pengguna harus login sebagai instruktur dengan password dan username "admin". Untuk lebih jelas lihat gambar3.

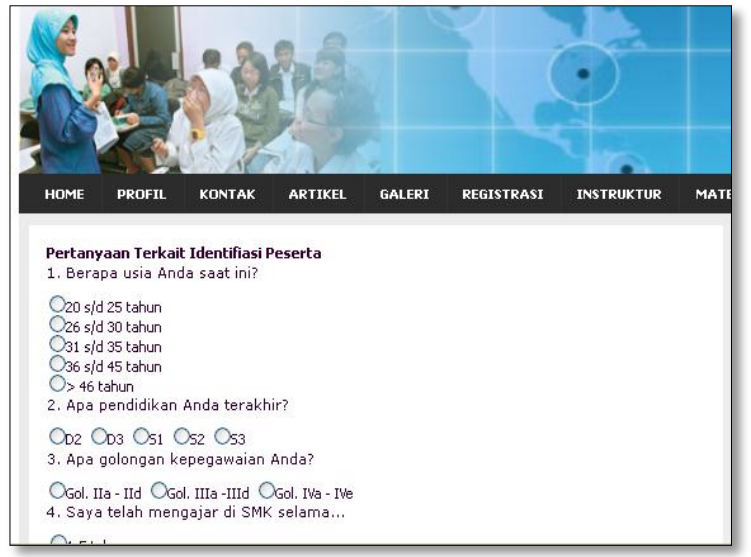

Gambar 3. Sajian Pertanyaan Identifikasi pada DSS (Instrumen)
Pendekatan yang dipakai DSS dalam pengambilan putusan menggunakan pendekatan SAW, pendekatan ini keputusan metode pelatihan $\left(\mathrm{A}_{\mathrm{i}}\right)$ dianggap sebagai sebuah FMADM (Fuzzy Multi Atribute Decision Making) dimana suatu putusan dipengaruhi banyak atribut yang saling menentukan.Dalam pengambilan keputusan yang memenuhi FMADM, diselesaikan melalui pendekatan SAW dengan langkah penyelesaian;

1) Menentukan alternatif dan kriteria sebagai acuan dalam pengambilan keputusan $\left(\mathrm{C}_{\mathrm{i}}\right)$. Adapun kriteria $\mathrm{C}_{1}$ s/d $\mathrm{C}_{13}$ adalah pertanyaan no. 24 s/d 36 (dalam pengujian DSS). Sedangkan alternatif $\left(\mathrm{A}_{\mathrm{i}}\right)$ berupa metode $\mathrm{A}_{1}=$ lapangan, $\mathrm{A}_{2}=$ simulasi, $\mathrm{A}_{3}=$ laboratorium, $\mathrm{A}_{4}=$ kasus, $\mathrm{A}_{5}=$ individual, $\mathrm{A}_{6}=$ seminar dan $\mathrm{A}_{7}=$ ceramah.

2) Pada uji white-box, pertanyaan yang dijawab adalah no. $26 \mathrm{~s} / \mathrm{d} 36$, atau dalam skrip ditulis dengan T1 s/d T13.

3) Melalaui analisis pengembangan instrumen IMM diberikan bobot preferensi (W) diberikan bobot 1 untuk $\mathrm{C}_{1} \mathrm{~s} / \mathrm{d} \mathrm{C}_{13}$.

4) Membetuk matriks keputusan dibentuk dari tabel kecocokan.

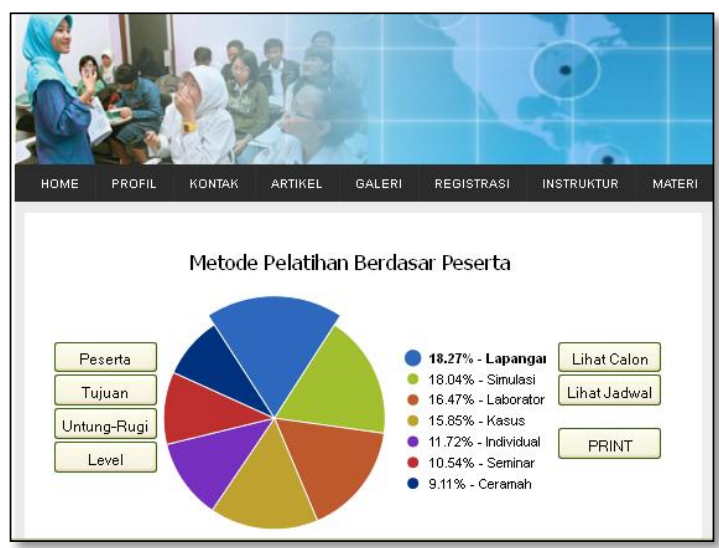

Gambar 4. Hasil Produk DSS (Diagram Pie Hasil Analisis)

5) Dilakukan perankingan hasil akhir (V) dengan terlebih dulu menjumlahkan baris $\mathrm{V}_{1} \mathrm{~s} / \mathrm{d} \mathrm{V}_{7}$ dari hasil kali bobot (W) dengan matriks ternormalisasi (R). Nilai terbesar dari hasil akhir $\left(\mathrm{V}_{\mathrm{i}}\right)$, ada pada $\mathrm{V}_{3}$ dengan nilai 10, artinya keputusan metode pelatihan e-learning yang tepat bagi calon peserta pada pengujian adalah laboratorium, hasilnya seperti pada gambar 4 . 


\section{Hasil Uji Alfa}

Uji alfa yang dilakukan oleh ahli software, ahli pengambilan keputusan dan praktisi pelatihan mencakup aspek content, function, usability, navigation, performance, compatibility dan security. Berdasarkan hasil uji alfa, diketahui tentang aspek-aspek yang sudak baik dan beberapa aspek yang perlu mendapat revisi, tentu dengan tujuan akhir DSS dapat bekerja secara optimal sesuai fungsi dan layak. Data yang diperoleh dari validasi ahli software, ahli pengambilan putusan dan praktisi pelatihan tersaji dalam bentuk ordinal dalam skala 5. Berdasarkan olah data dari 45 butir indikator, maka kriteria penilaian kualitas DSS oleh ahli memperoleh rerata skor 3,92 dengan standar deviasi 0,32. Data mengenai penilaian kualitas DSS yang dilakukan oleh 3 validator terlihat dalam tabel 48.

Tabel 3. Hasil Rerata Penilaian Aspek DSS oleh Ahli

\begin{tabular}{lll}
\hline No & \multicolumn{1}{c}{$\begin{array}{c}\text { Aspek DSS yang } \\
\text { Dinilai }\end{array}$} & Skor \\
\hline 1. & Content & 3,85 \\
2. & Function & 4,14 \\
3. & Usability & 3,79 \\
4. & Navigation & 4,10 \\
5. & Performance & 4,13 \\
6. & Compatibility & 4,40 \\
7. & Security & 3,33 \\
& Rerata & 3,92 \\
& Std. Dev & 0,32 \\
\hline
\end{tabular}

Untuk memperjelas informasi hasil penilaian aspek-aspek DSS oleh ahli, dapat dilihat pada gambar 5 .

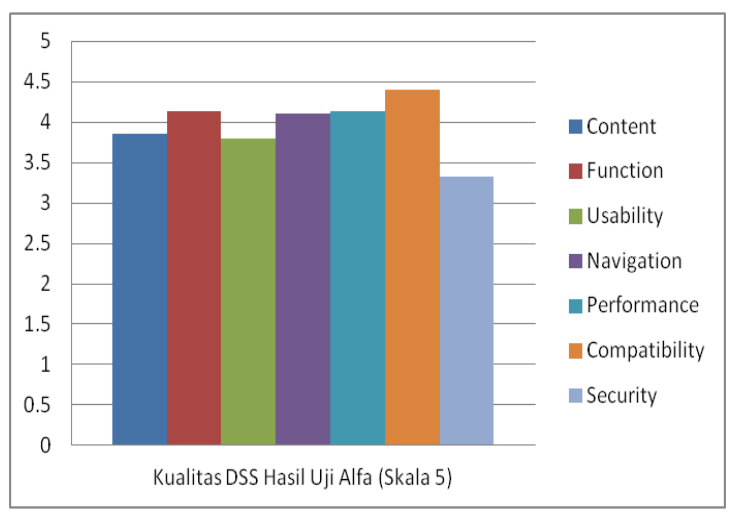

Gambar 5. Histogram Hasil Uji Alfa
Sesuai pedoman konversi di atas, rerata skor hasil uji alfa oleh ahli 3,92. Sehingga nilai tersebut berada pada interval skor $3,4<$ $\mathrm{X} \leq 4,2$ atau dapat disimpulkan bahwa penilaian ahli software dan ahli pengambilan keputusan dan praktisi terhadap konten DSS masuk dalam kategori baikdan memenuhi persyaratan untuk diuji beta.

\section{Hasil Uji Beta}

Analisis dilakukan berdasarkan data yang diperoleh dari uji beta terhadap peserta pelatihan dan instruktur (guru). Uji beta dilakukan pada 17 responden (peserta dan instruktur). Untuk responden peserta terdiri dari; a) 4 guru dari SMK Negeri 2 Depok sebagai potential user, b) 4 guru dari SMK Muhammadiyah 3 Yogyakarta sebagai average user dan c) 5 guru dari SMK Bumantara Magelang sebagai slow learner user, sehingga total 13 responden.

Sedangkan responden instruktur adalah para guru yang pernah menjadi instruktur sebanyak 4 responden. Hasil uji beta DSS yang diperoleh dari 7 aspek penilaian dengan 26 indikator, diperoleh hasil skor rerata 4,02 dengan standar deviasi 0,12 . Informasi terkait penilaian responden pada uji beta tersaji pada tabel 4.

Tabel 4. Hasil Rerata Penilaian Aspek DSS oleh Pengguna

\begin{tabular}{ccc}
\hline No & Aspek DSS yang Dinilai & Skor \\
\hline 1. & Content & 4,03 \\
2. & Function & 4,21 \\
3. & Usability & 4,06 \\
4. & Navigation & 4,02 \\
5. & Performance & 4,00 \\
6. & Compatibility & 3,79 \\
7. & Security & 4,00 \\
& Rerata & 4,02 \\
& Std. Dev. & 0,12 \\
\hline
\end{tabular}

Untuk memperjelas informasi hasil penilaian aspek-aspek DSS oleh responden (peserta dan instruktur) dapat diperjelas melalui gambar 6 . 


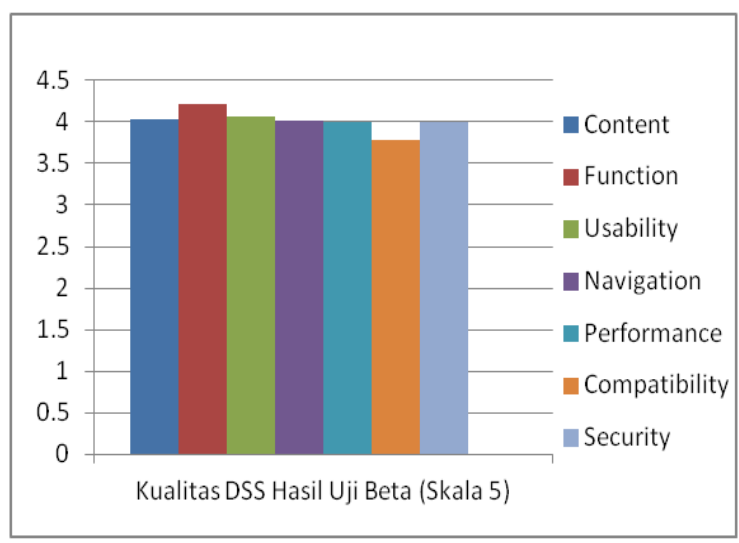

Gambar 6. Histogram Hasil Uji Beta

Melihat histogram hasil uji beta di atas, selanjutnya untuk dapat menyimpulkan nilai rerata skor menjadi penilaian kualitatif perlu konversi data kuantitatif ke data kualitatif skala 5, seperti diuraikan pada tabel 1 di atas. Berdasarkan hasil perhitungan nilai konversi data kuantitatif ke data kualitatif skala 5 tersebut rerata skor hasil uji beta oleh responden 4,02 .

Jika melihat tabel konversi nilai tersebut berada pada interval skor $3,4<\mathrm{X} \leq$ 4,2 atau dapat disimpulkan bahwa penilaian responden calon pengguna (peserta dan instruktur pelatihan) terhadap DSS yang dikembangkan masuk dalam kategori baikdan memenuhi persyaratan untuk dievaluasi.

\section{Hasil Uji Evaluasi}

Analisis data evaluasi dilakukan setelah uji alfa dan uji beta Setelah kedua proses tersebut selesai berikut revisisnya, barulah dilakukan evaluasi melalui uji coba di lapangan sesungguhnya. Evaluasi dimaksudkan untuk mengidentifikasi dan mengetahui kekurangan produk dan mengetahui akurasi DSS dalam menentukan metode pelatihan e-learning. Evaluasi dilaksanakan di SMK Negeri 1 Kalasan pada 30 guru calon peserta yang ikut pelatihan dengan pertimbangan penentuan berdasarkan Peserta didapati metode pelatihan yang cocok adalah Laboratorium.Hasil evaluasi DSS dalam membantu instruktur menentukan metode untuk kelompok peserta (30 orang), memberikan hasil analisis SAW seperti pada Gambar 7.

Sehingga pada evaluasi ini, pelatihan menggunakan metode Laboratorium. Analisis selanjutnya mengarah pada akurasi DSS dalam menentukan metode pelatihan e-learning. Prinsip pengujian akurasi dilakukan dengan membandingkan metode pelatihan yang dipakai sebagai hasil keputusan, dalam hal ini sebagai kondisi ideal (Metode Laboratorium). Untuk mengetahui nilai akurasi maka data ideal (Yn) dibandingkan dengan data empiris hasil evaluasi $(\mathrm{Xn})$, maka diperoleh data tersaji dalam tabel 5.

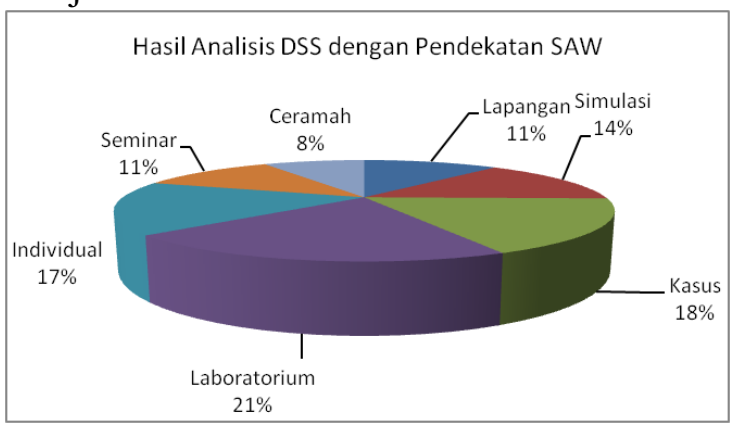

Gambar 7. Dagram Pie Hasil Evaluasi

Tabel 5. Akurasi DSS dalam Menentukan Metode Pelatihan Berdasarkan Pertimbangan "Tujuan"

\begin{tabular}{ccccc}
\hline No. & $(\mathbf{Y n})$ & $(\mathbf{X n})$ & $\mathbf{e}$ & $\begin{array}{c}\text { Akurasi } \\
\text { \% }\end{array}$ \\
\hline 1. & 59 & 55 & 4 & 93,22 \\
2. & 59 & 56 & 3 & 94,92 \\
3. & 59 & 54 & 5 & 91,53 \\
4. & 59 & 43 & 16 & 72,88 \\
5. & 59 & 57 & 2 & 96,61 \\
6. & 59 & 53 & 6 & 89,83 \\
7. & 59 & 56 & 3 & 94,92 \\
8. & 59 & 55 & 4 & 93,22 \\
9. & 59 & 56 & 3 & 94,92 \\
10. & 59 & 48 & 11 & 81,36 \\
11. & 59 & 51 & 8 & 86,44 \\
12. & 59 & 46 & 13 & 77,97 \\
13. & 59 & 42 & 17 & 71,19 \\
14. & 59 & 40 & 19 & 67,80 \\
15. & 59 & 54 & 5 & 91,53 \\
16. & 59 & 51 & 8 & 86,44 \\
17. & 59 & 54 & 5 & 91,53 \\
18. & 59 & 57 & 2 & 96,61 \\
19. & 59 & 54 & 5 & 91,53 \\
20. & 59 & 56 & 3 & 94,92 \\
21. & 59 & 49 & 10 & 83,05 \\
22. & 59 & 49 & 10 & 83,05 \\
23. & 59 & 55 & 4 & 93,22 \\
24. & 59 & 57 & 2 & 96,61 \\
& & Rerata & & $\mathbf{8 8 , 1 4}$ \\
\hline & & & & \\
\hline
\end{tabular}




\section{SIMPULAN DAN SARAN}

\section{Simpulan}

1. Produk DSS dalam membantu pengambilan putusan metode pelatihan e-learning SMK menghasilkan; (a) mekanisme pendekatan metode SAW sebagai inti DSS dalam menentukan metode pelatihan $e$-learning sesuai kondisi ragam peserta yang memenuhi syarat FMADM. Proses analisis DSS dimulai dari pemberian bobot untuk setiap kriteria (Ci), membuat matriks keputusan $(\mathrm{X})$ lalu mencari nilai maksimum dari matrik ternormalisasi $(\mathrm{R})$ sebagai hasil putusan metode pelatihan $e$ learning; (b) Hasil pengembangan DSS bagi instruktur dalam memutuskan metode pelatihan e-learning mampu memberi alternatif keputusan secara cepat melalui empat pertimbangan dalam menentukan metode untuk pelatihan e-learning berbasis Moodle. Instruktur dapat memilih salah satu dari empat pertimbangan yaitu; berdasarkan peserta, berdasarkan tujuan, berdasarkan untung-rugi, dan berdasarkan level dalam bentuk persentase.

2. Kualitas DSS dalam membantu instruktur mengambil putusan menentukan metode pelatihan e-learning sebagai berikut; (a) Hasil uji alfa menunjukkan rerata skor 3,92 atau dalam kategori "baik", sedangkan hasil uji beta menunjukkan rerata skor 4,02 juga dalam kategori "baik"; (b) Akurasi DSS melalui pendekatan SAW dalam menentukan metode pelatihan $e$ learning diketahui melalui hasil evaluasi terhadap 24 peserta pelatihan, memiliki akurasi $88,14 \%$.

\section{Saran}

Rekomendasi implikatif dari temuan penelitian ini untuk pengembangan produk DSS selanjutnya dapat memperhatikan hal-hal berikut;

1. Perangkat pelatihan (jadwal dan materi) dapat diintegrasi dalam DSS secara adaptif sesaui metode terpilih.

2. Perlu melakukan analisis lebih tajam terhadap jumlah butir kriteria.

3. Pengembangan lanjutan, perlu penggabungan SAW dengan pendekatan lain misalnya Weighted Product (WP), Analytic Hirarchy Process (AHP), Profile
Matching (PM), TOPSIS maupun ELECTRE untuk hasil yang lebih akurat.

4. Penelitian lanjutan perlu menguji kepresisian dalam melalui penyelenggaraan pelatihan e-learning di beberapa SMK.

\section{Daftar Pustaka}

Adwan, A. A. (2012).Implementing e-learning in the Jordanian higher education system: Factors affecting impact. [Versi elektronik]. International Journal of Education and Development using Information and Communication Technology (IJEDICT), 2012, Vol. 8, Issue 1, pp. 121-135.

Ardian. (2012). Model Decission Support System untuk Pengembangan Program Studi di Perguruan Tinggi. Diakses tanggal 30 Oktober 2012, dari http:// pps.uny.ac.id/berita/model-decisionsupport-system-untuk-pengembanganprogram-studi-di-perguruantinggi.htmls.uny.ac.id.

Assotition South East Asia Nations. (2009). Roadmap for an ASEAN community 2009-2015. Jakarta: ASEAN Secretariat.

del Mar, C. M. (2006, July). Teacher training in ICT-based LEARNING settings: design and implementation of an on-line instructional model for english language teachers (Desertasi doctor PheonixUniversity) pp. 4-88.

Frize, M.\& Frasson, C. (August 2000). Workshop: Cognitive and social sciences foundations for medical education and training in the information technology clinical and investigative medicine; 23 , 4; ProQuest Science Journals pg. 266.

Goldstein, I. L., \& Ford, J.K. (2003). Training in organization: need assessment, development and evaluation. $4^{\text {th }} e d$. Wadsworth Group.

Jardiknas. (2012). Integrasi TIK. Diambil pada tanggal 10 Agustus 2012, dari http://jardiknas.kemdiknas.go.id/

Kemendiknas. (2009). Permendiknas No. 78 Tahun 2009tentangKebijakan RSBI dan RSBI. 
Kubr, M. \& Prokopenko, J. (1989). Diagnosing management training and development needs: Concepts and techniques. Geneva: International Labor Office.

Kusrini. (2007). Konsep dan aplikasi sistem pendukung keputusan. Yogyakarta: Andi Offset.

Lee, W. \& Owens, D. L. (2004). Multimedia based instructional design: Computer based training web based training distance broadcast training, performance based solutions $2^{\text {nd }} e d$. San Fransisco: Pfeiffer.

Lynton, R., P. \& Pareek, U. (1992). Pelatihan dan pengembangan tenaga kerja. (Terjemahan Redaksi Pustaka Binaman Pressindo). Jakarta: Karya Unipress. (Buku asli diterbitkan tahun 1968).

MOODLE. (2012). About MOODLE LMS. Diakses pada tanggal 1 Agustus 2012, dari http://moodle.org/about/

Naidu, S. (2006). A guidebook of principles, procedures and practices. Cemca, New Delhi.

Naser, A., et.al (2011). A prototype decision support system for optimizing the effectiveness of elearning in educational institutions. International Journal of Data Mining \& Knowledge Management Process (IJDKP) Vol.1, No.4, July 2011.

Pressman, R. S. (2010). Software engineering: A practitioner's approach, $7^{\text {th }} \mathrm{ed}$. New York : Mc Graw Hill.

Rosen, L. D. (1993). Treating technophobia: A longitudinal evaluation of the computerphobia reduction program. Journal of Computer in Human Behavior, 9, 2750.

Sukardjo. (2005). Desain pembelajaran: Evaluasi pembelajaran. Handout perkuliahan: Program Pascasarjana Universitas Negeri Yogyakarta.

Turban, E., Jay, E.A, \& Peng, L.J. (2005). Decision support system and intelligent system. (Terjemahan Dwi Prabantini). Yogyakarta: Andi Offset (buku asli diterbitkan tahun 1992).

Wedel, K. \& Brown, F. G. (1974). Assesing training needs. Washington: National Training and Developmnet Service Press. 